\title{
REVIEW OF THE MEETINGS OF THE GOVERNMENT OF THE RF IN MARCH 2013
}

\author{
M.Goldin
}

In March 2013, discussed among other things at the meetings of the Presidium of the Government of the Russian Federation were the following issues: draft law on the Principles of Public-Private Partnership in the Russian Federation and draft law on Public Entities in the Russian Federation.

On March 7, discussed at the meeting of the Government of the Russian Federation was the draft law on the Principles of Public-Private Partnership in the Russian Federation. It is to be noted that the draft law was developed by the Ministry of Economic Development of the Russian Federation in accordance with Instructions of December 23, 2011 and April 28, 2012 of the Government of the Russian Federation.

According to Article 1 of Part 2 of the draft law, after approval the document will set guidelines for state regulation of public-private partnership (PPP) and powers of the Russian Federation, constituent entities of the Russian Federation and municipal entities in fulfillment of agreements on public-private partnership. At the same time the provisions of the draft law in question will not apply to relations related to implementation of projects on the basis of a public-private partnership at the expense of investment funds' budget allocations. Such projects are likely to be carried out in accordance with the legislation on concessions. In addition to the above, in accordance with the draft law provisions of Federal Law No. 94-FZ of July 21, 2005 on Placement of Orders on Goods Supplies, Doing of Jobs and Rendering of Services for Public and Municipal Needs will not apply to conclusion and implementation of agreements on PPP.

The draft law provides a notion of the public-private partnership (PPP). PPP means such cooperation between the public partner on the one side and the private partner on the other side as is carried out on the basis of the agreement - concluded on the basis of the results of tender procedures - on public-private partnership aimed at upgrading the quality and better provision of services to people and attraction of private investments to the economy.

In accordance with the draft law, PPP's purpose consists in provision to the private partner of the property - which is required for carrying out activities provided for by the agreement on public-private partnership - in ownership and (or) use and (or) the right to use the outputs of intellectual activities or individualization funds required for fulfillment of the agreement on publicprivate partnership.

The specifics of implementation of individual forms of public-private partnership and individual types of agreements on public-private partnership should to be regulated by individual federal laws.

In PPP, private partners are not allowed to be:

- State-owned companies;

- State corporations;

- GUP and MUP;

- Public and municipal entities;

- business entities in whose charter capital $100 \%$ of shares or interests is owned by the Russian Federation, constituent entity of the Russian Federation or municipal entity.

The draft law removes a number of problems and differences which exist in the effective federal legislation on PPP. The draft law in question eliminates a discrepancy between the practice of implementation of PPP projects and the norm of Article 17 of Part 3 of Federal Law No. 135FZ of July 26, 2006 on Protection of Competition under which it is prohibited in carrying out of auctions for placement of orders on goods supplies, doing of jobs and rendering of services for public and municipal needs to limit competition between participants in the auction by means of including in the composition of the lots the produce (goods, jobs and services) which is neither technologically nor functionally related to goods, jobs and services whose supplies, fulfillment and rendering are the subject of the auction. Application of the above norm of the Law on Protection 
of Competition could have resulted in a PPP project united by a common purpose being "torn" into multiple auctions with different bidders.

Also, the draft law introduces amendments into the Land Code of the Russian Federation; the above amendments provide for leasing of a land plot for activities specified in agreements on PPP without both holding of auctions (tenders) and preliminary approval of places for location of projects.

At the meeting of the Government of the Russian Federation, the draft law on the Principles of Public-Private Partnership in the Russian Federation was approved and submitted to the State Duma of the Russian Federation. In addition to the above, in preparation of the draft law for consideration by the State Duma in the second reading A. Belousov, Minister of Economic Development of the Russian Federation and A. Siluanov, Minister of Finance of the Russian Federation were instructed to specify provisions as regards introduction of amendments into the Land Code of the Russian Federation and the Federal Law on Placement of Orders on Goods Supplies, Doing of Jobs and Rendering of Services for Public and Municipal Needs.

On March 21, the draft federal law on Public Entities in the Russian Federation and Amendment of Individual Statutory Acts of the Russian Federation was discussed at the meeting of the Government of the Russian Federation.

The draft law was developed by the Ministry of Economic Development of the Russian Federation within the framework of the reform of the civil legislation as regards forms of incorporation of entities in pursuance of Instructions No.Pr-1793 of July 17, 2012 of the President of the Russian Federation. It is to be noted that earlier in August 2011 the Ministry of Economic Development of the Russian Federation submitted for public debates the federal draft law on Public Entities in the Russian Federation. However, on the basis of the feed-back received it was decided that further development of the draft law was required.

After being approved as a federal law, the draft law provides for introduction into the legislation of the Russian Federation of a new form of incorporation of non-profit organizations - a public entity. The draft law sets a general approach both to the procedure of establishment, operation, management and liquidation of such companies, as well as a number of other issues.

Public entities are to replace the existing specialized forms of incorporation of non-profit organizations through which the government participates in civil law relations: state corporations and state-owned companies ${ }^{1}$. It originates from the following:

- first, the schedule plan of measures aimed at restructuring and liquidation of Rosavtodor, a state-owned company approved by Resolution No. 6793 n-13 of December 29, 2010 of the Premier of the Government of the Russian Federation;

- second, the close classification of the forms of incorporation of non-profit organizations specified in draft law No. 47538-6/2 on Amendment of Chapter 4 of Part 1 of the Civil Code of the Russian Federation, Article 1 of the Federal Law on Insolvency (Bankruptcy) and Recognition as Null and Void of Individual Provisions of Statutory Acts of the Russian Federation which concern exclusively public entities.

At the same time, there is a reservation in draft law No. 47538-6/2; under the above reservation provisions of the Civil Code of the Russian Federation as regards legal entities are applied to Rosavtodor, a state-owned company, as well as other legal entities established by the Russian Federation on the basis of special federal laws to the extent that otherwise is not provided for by a special federal law on a relevant legal entity. So, in Russia for an uncertain period of time there will be actually three specialized forms of incorporation of non-profit government organizations with almost the same status.

The draft law is meant to liquidate many disadvantages of the existing legal regulation of state corporations and state-owned companies which along with a high extent of their autonomy provide the government with inefficient instruments of control over their activities.

The draft law was approved at the meeting of the Government of the Russian Federation and submitted to the State Duma of the Russian Federation.

1 At present, there are seven state corporations: Rosatom, Rostekhnologia, Rosnano, the Agency for Insurance of Deposits, the Fund for Assistance in Restructuring of Housing and Public Utilities, The Bank for Development and Foreign Economic Affairs (Vneshekonombank), the State Corporation for Building of Olympic Projects and Development of the City of Sochi as a Mountain Resort and Rosavtodor, a state-owned company. 